\title{
POTENSI BUAH SALAK (Salacca edulis, R.) SEBAGAI SUPLEMEN HIPOLIPIDEMIK DITINJAU DARI GAMBARAN HISTOPATOLOGI JANTUNG DAN HEPAR MENCIT YANG DIBERI DIET RENDAH LEMAK
}

\author{
SNAKE FRUIT POTENT (Salacca edulis, R.) AS HYPOLYPIDEMIC SUPPLEMENT \\ FROM THE VIEW OF HEART HYSTOPATHOLOGY AND FAT LOW DIET OF MICE \\ HEPAR
}

\author{
Tri Hardjana*, Kartika Ratna Pertiwi dan Tutik Rahayu \\ Jurusan Pendidikan Biologi, Fakultas MIPA, Universitas Negeri Yogyakarta \\ *email: annandroo@ymail.com
}

Diterima 5 Agustus 2016 disetujui 5 September 2016

\begin{abstract}
Abstrak
Penelitian ini bertujuan mengetahui struktur histopatologi jantung mencit yang diberi sari buah salak (Salacca edulis, R) dan diet lemak hewani dan untuk mengetahui struktur histopatologi hati mencit yang diberi sari buah salak (Salacca edulis, R) dan diet lemak hewani. Penelitian ini mengguanakan metode penelitian eksperimen dengan tujuan untuk mengukur respon yang muncul dari suatu obyek sebagai akibat adanya perubahan suatu faktor yang mengenainya. Tempat penelitian dilakukan di Animal House Universitas Negeri Yogyakarta dan pengamatan preparat dilakukan di laboratorium Zoologi Fakultas MIPA Universitas Negeri Yogyakarta, selama kurun waktu bulan Juni sampai Oktober 2015. Variabel penelitian bebas berupa sari buah salak, sedangkan variabel tergayut yaitu gambaran histopatologi hati meliputi kerusakan batas sel dan infiltrasi sel lemak dan diameter vena sentralis sedangkan jantung meliputi kerusakan endotel dan infiltrasi sel lemak. Data dianalis secara deskriptif untuk menyajikan sebaran frekuensi. Keterkaitan antar variabel tersebut disajikan dalam format tabel silang dan dianalisis dengan statistik deskriptif. Hasil penelitian menyatakan (1) Struktur histopatologi pembuluh darah jantung mencit yang diberi sari buah (Salacca edulis, R) dan diet lemak hewani mengalami kerusakan endotel dan infiltrasi lemak lebih kecil dibandingkan struktur histopatologi pembuluh darah jantung pada mencit yang diberi tambahan diet lemak; (2) Struktur histopatologi sel hepar mencit yang diberi sari buah salak (Salacca edulis, R) dan diet lemak hewani mengalami kerusakan endotel dan infiltrasi lemak lebih banyak dibandingkan struktur histopatologi sel hepar pada mencit yang diberi tambahan diet lemak.
\end{abstract}

Kata kunci: buah salak, lemak, histopatologi, hepar, jantung

\begin{abstract}
This study aims to study the structure of the heart histopathologic and the liver of white rat given the Salacca edulis, $R$ extract and animal fat diet. This research used experimental research with the aim to measure the response of an object that appears as a result of the change in a factor that is about it. Place of research did in animal house of Yogyakarta State University and observation of preparations did in the laboratory of biological, faculty of mathematics and natural science, at Yogyakarta State University during the months of June to October 2015. Independent study variables such as salacca edulis, $R$ extract, while the dependent variable is the description of liver histopathology includes damaged cells and fat cell infiltration, while the heart includes endothelial damage and infiltration of fat cells. Data were analyzed descriptively to present the frequency distribution, Linkages between these variables are presented in table format and analyzed with cross descriptive statistics. The results are (1) the structure of the heart histopathologic white rat given salacca edulis, $R$ extract and animal fat diet have endotel defect and fat infiltration less than structure of the heart histopahologic white rat given animal fat diet. (2) the structure of the liver histopathologic white rat given salacca edulis, $R$ extract and animal fat diet have endotel defect and fat infiltration more than structure of the heart histopahologic white rat given animal fat diet.
\end{abstract}

Keywords: Salacca edulis, $R$, fat, histopathology, liver, heart 


\section{Pendahuluan}

Kabupaten Sleman adalah salah satu kabupaten di Propinsi D.I Yogyakarta yang memiliki luas wilayah 574,82 Km2 (18,10\% dari luas Prop.DIY) dan terletak di lereng Selatan Gunung Merapi. Salah satu komoditas unggulan Kabupaten Sleman adalah salak pondoh. Sleman merupakan sentra penghasil dan penelitian buah dan bibit Salak Pondoh. Terdapat 4.067.975 rumpun dengan produksi $266.938 \mathrm{Kw} / \mathrm{Tahun}$ (Pemkab Sleman, 2009). Hal tersebut menyebabkan daerah tersebut terkenal sebagai daerah agrowisata dengan wisata suasana alam yang sejuk dan alami, serta memiliki potensi perkebunan salak pondoh yang berkualitas. Salak Pondoh menjadi sebuah ikon yang tidak dapat dipisahkan dari Kabupaten Sleman dan Yogyakarta. Salak pondoh dari Sleman memiliki rasanya yang manis dan segar, rasa salak Pondoh dari Sleman juga berbeda dengan rasa salak dari tempat lain. Tumbuh di daerah ketinggian sedang dengan tingkat kesuburan yang bagus di sekitar lereng Merapi menjadikan rasa salak Pondoh berbeda dengan salak dari daerah lain. Salak Pondoh tidak hanya manis dan segar tetapi mampu menembus pasar ekspor dan menjadi sebuah komoditas tanaman yang menguntungkan bagi petani.

Dampak abu dan material vulkanik dari erupsi gunung berapi pada salak pondoh merupakan masalah teraktual yang dihadapi petani salak pada paska erupsi gunung merapi tahun 2010. Temuan Aksan dkk (2010) dalam studi kasus kawasan agrowisata salak Pondoh, Turi, Sleman, Yogyakarta di lahan Salak Pondoh Di Desa Girikerto, Wonokerto serta Donokerto, Turi Kec. Turi Kabupaten Sleman, terlihat berbagai kerusakan yang terjadi khususnya pada tahap pertanaman salak. Berupa meterial awan panas, pasir, debu vulkanik bahkan lumpur berpasir yang ternyata mengganggu agroekosistem sekitar salak pondoh sekitar. Kerusakan pertanaman salak akan mengakibatkan penurunan perekonomian petani salak. Pengembalian kondisi tersebut seperti semula, selain kembali melakukan pemulihan perkebunan salak, perlu adanya cara untuk tetap menjaga nama salak pondoh sebagai ikon yang tidak dapat dipisahkan dari Kabupaten Sleman dan Yogyakarta. Penelitian tentang manfaat salak pondoh juga dapat membantu untuk memberikan nilai lebih terhadap salak pondoh. Pengetahuan tentang manfaat dari salak pondoh dalam bidang kesehatan diharapkan salak pondoh akan semakin dibutuhkan oleh masyarakat dan secara langsung akan memberikan dampak positif terhadap petani salak.

Penyakit jantung dan pembuluh darah menjadi penyebab utama kematian di negara maju dan negara berkembang pada akhir abad 20. Berdasarkan Survei Kesehatan Rumah Tangga (SKRT) tahun 2013, kematian akibat penyakit jantung dan pembuluh darah di Indonesia sebesar 26,3\%, meningkat dibandingkan data kematian di rumah sakit tahun 2005 sebesar 16,7\%. Prevalensi ini meningkat dari tahun ke tahun sehingga penyakit jantung menduduki peringkat pertama sebagai penyebab kematian (Ruhyana, 2007). Penyakit jantung koroner merupakan salah satu jenis kelainan yang disebabkan oleh penyempitan atau penghambatan pembuluh arteri yang mengalirkan darah ke otot jantung (Soeharto, 2000:30). Penyakit ini umumnya menjangkiti penderita-penderita di atas umur 40 tahun, tetapi dalam dekade terakhir ini sudah sering didapati pada penderita yang lebih muda. Faisal (2000:1) mengatakan bahwa penyakit jantung koroner berhubungan erat dengan pola hidup sehari-hari yang tidak sehat.

Pola hidup yang tidak sehat yang sering kali dilakukan oleh masyarakat adalah mengenai pola memilih makanan. Banyak sekali makanan yang mengandung lemak saat ini. Soeharto (2000:30) menyebutkan bahwa konsumsi jenis makanan berlemak yang berlebihan akan mengakibatkan terbentuknya kolesterol dalam tubuh yang melebihi batas normal. Kolesterol dalam batas normal sangat diperlukan dalam tubuh di antaranya sebagai komponen pembentuk dinding sel, garam empedu, dan hormon, namun jika dalam tubuh kolesterol berlebih dapat menyebabkan terjadinya penyempitan pembuluh darah atau biasa disebut aterosklerosis. Aterosklerosis merupakan suatu proses pelapisan dinding nadi oleh endapanendapan bahan berlemak yang disebut ateroma. Penyebab pastinya tidak diketahui tetapi berbagai faktor resiko terbukti telah meningkatkan peluang aterosklerosis. Faktor resiko tersebut antara lain adalah kenaikan kolesterol darah, kebiasaan merokok, diabetes melitus, kebiasaan makanmakanan berlemak, riwayat kondisi dalam keluarga, obesitas, kurang olahraga dan stres (Patel, 1998:16).

Jantung dan hati memiliki hubungan dengan kolesterol. LDL (Low Density Lipoprotein) kolesterol atau kolesterol lipoprotein berkepadatan rendah adalah kolesterol jahat, karena kolesterol LDL melekat pada dinding arteri dan bisa 
menyebabkan terjadinya penutupan arteri. Kolesterol lipoprotein berkepadatan tinggi dikenal sebagai kolesterol baik atau HDL (High Density Lipoprotein) berperan membawa kembali kolesterol buruk ke organ hati untuk pemrosesan lebih lanjut. Kadar HDL yang tinggi akan melindungi jantung dari penyakit, kadar LDL dalam kategori yang sangat baik bisa berisiko untuk terkena penyakit jantung. Kelebihan lemak juga mempunyai dampak terhadap keadaan hati, kondisi yang dinamakan non-alcohol steatohepatitis (NASH). NASH adalah keadaan penumpukan lemak dalam hati sehingga menciptakan jaringan parut dan sirosis. Kelebihan berat badan (obesitas) meningkatkan risiko terbentuknya non-alcohol steato-hepatitis.

Terdapat bermacam-macam cara untuk mencegah bahkan menyembuhkan berbagai penyakit yang dialami oleh masyarakat. Terdapat cara pengobatan modern maupun konvensional. Walaupun perdebatan para medis tentang bisa atau tidaknya penyakit kronis tersebut untuk disembuhkan, tidak sedikit penderita yang kembali mencari sistem pengobatan tradisional. Keunggulan dari pemakaian obat tradisional adalah dapat melepaskan ketergantungan dari obat kimiawi dan biaya yang dikeluarkan relatif terjangkau khususnya bagi masyarakat yang kurang mampu.

Pengendalian kadar kolesterol pada darah dapat dilakukan dengan melakukan diet yang dapat menurunkan kadar kolesterol pada darah atau bersifat hipokolesterolemik. Pengaturan diet yang dikonsumsi merupakan cara yang sederhana, murah, dan aman untuk pengendalian kadar kolesterol pada darah. Menurut Povey (1996:106), diet yang baik untuk penderita hiperlipidemia yang dapat berfungsi menurunkan kadar kolesterol harus makanan yang mengandung karbohidrat termasuk serat pangan, rendah sukrosa dan glukosa, rendah kolesterol dan asam-asam lemak jenuh, serta mengandung protein yang memadai. Bahan makanan yang memiliki potensi menurunkan kadar kolesterol darah adalah buah-buahan terutama yang mengandung vitamin $\mathrm{C}$ dan memiliki serat.

Pencarian dan penemuan bahan alam atau obat alami yang murah dan mujarab untuk mengobati dan mencegah penyakit degeneratif, diketahui bahwa sayuran maupun buah-buhan contohnya buah salak (Salacca edulis, R.) dapat mengendalikan kadar kolesterol pada darah. Kandungan buah salak (Salacca edulis, R) pada 100 gram bagian buah yang dapat dimakan antara lain mengandung air $(78,00 \mathrm{mg})$, protein $(0,40 \mathrm{gr})$, serat kasar, vitamin C (2,00 mg), kalasium $(28,00$ $\mathrm{mg}$ ), fosfor (18,00 mg) (I ketut Suter, 1998:137). Vitamin C berkisar antara 1,54-2,93 mg/100 gram dan serat kasar 3,23 mg/gram, serat zat aktif saponin 1,05 $\mathrm{mg} / 00$ gram dan flavanoida 1,53 $\mathrm{mg} / 100$ gram.

Kandungan fitokimia dalam buah salak adalah flavanoida yang dapat menurunkan kadar kolesterol. Menurut Rusdi (1988:14), yang dimaksud dengan fitokimia adalah senyawasenyawa aktif biologis yang terdapat dalam simplisia tumbuhan. Senyawa aktif flavanoida berguna sebagai anti oksidan dalam tubuh yang berfungsi dalam meningkatkan toleransi glukosa, mencegah jantung koroner, meningkatkan fungsi sel beta pankreas dan dapat menekan kolesterol dalam tubuh. Peran dari vitamin $\mathrm{C}$ adalah melindungi kesehatan tubuh manuasia, seperti pembentukan kolagen (Linder,1992: 166-168), meningkatkan daya tahan tubuh, meningkatkan aktivitas fagositosis sel darah putih dan meningkatkan absorbsi zat besi dalam usus (Dedy, 1993:41). Menurut Potter (Bunga, 2009: 2), serat kasar dapat menurunkan kadar kolesterol karena serat kasar dapat mengganggu proses sintesis kolesterol. Manfaat serat antara lain mampu melindungi usus dari gangguan sembelit (kontipasi), diare, divertikulum, wasir, dan kanker usus, selain itu serat makanan juga mencegah terjadinya gangguan metabolisme, sehingga tubuh terhindar dari kegemukan dan kemungkinan serangan penyakit diabetes millitus, jantung koroner, dan batu empedu. Penelitian ini dilakukan untuk mendapat informasi tentang potensi salak sebagai agen hipolipidemik dengan melihat gambaran histologi hati dan jantung pada mencit yang telah mendapat perlakuan pemberian sari buah salak dan diet lemak hewani.

\section{Metode Penelitian}

Penelitian ini menggunakan metode penelitian eksperimen dengan tujuan untuk mengukur respon yang muncul dari suatu obyek sebagai akibat adanya perubahan suatu faktor yang mengenainya. Penelitian pemeliharaan, pemberian perlakuan, pengambilan sampel darah mencit dilakukan di Animal House Universitas Negeri Yogyakarta sementara pengamatan preparat dilakukan di laboratorium zoologi Fakultas MIPA Universitas Negeri Yogyakarta. Waktu penelitian: bulan Juni sampai Oktober 2015. Variabel bebas: Sari buah salak; Variabel tergayut preparat hati : (1) Kerusakan batas sel (2) Infiltrasi sel lemak; 
variable tergayut preparat jantung : (1) Kerusakan endotel (2) Infiltrasi sel lemak.

Subjek penelitian adalah 21 ekor mencit yang dibagi ke dalam 3 kelompok yaitu: kelompok A yang diberi BR II tanpa diet lemak hewani, kelompok B yang diberi BR II dan diet lemak hewani, kelompok $\mathrm{C}$ yang diberi BR II, diet lemak dan sari buah salak.

Cara kerja dalam penelitian ini adalah sebagai berikut: (1) Mencit uji dimatikan terlebih dahulu dengan membiusnya. Kemudian didiamkan beberapa menit di atas bak paraffin sampai tidak bergerak lagi; (2) Pembedahan dilakukan pada hewan uji yang telah mati untuk pengmbilan organ yang akan digunakan sebagai preparat. Labelling (pemberian label) Organ hepar dan jantung di tempeli label yang sesuai. Permukaaan tulisan ditelungkupkan kemudian di masukkan kedalam fixative maka kertas akan melekat erat karena terjadi koagulasi; (3) Organ hepar yang telah diberi label langsung dimasukkan ke dalam fixative, agar tidak terjadi autolysis post mortable. Dalam hal ini fixatve yang digunakan adalah larutan formalin $10 \%$; (4) Proses pencucian dilakukan langsung menggunakan larutan alkohol mulai dari 30\%, $40 \%, 50 \%$ dan 60\%; (5) Dehidrasi adalah menggantikan molekul air dengan molekul alkohol bertingkat dari konsentrasi rendah hingga absolut dengan waktu tertentu; (6) Proses ini bertujuan menghilangkan alkohol agar paraffin dapat masuk ke dalam jaringan. Proses penjernihan ini menggunakan toluol tujuannya agar preparat tetap lunak, walaupun lama berada didalam toluol preparat tidak akan mengalami kerusakan sitologik; (7) Proses infiltrasi dilakukan di dalam oven (incibator) dengan temperatur $55^{\circ} \mathrm{C}-60^{\circ} \mathrm{C}$, atau dapat menggunakan kotak logam yang diberi lampu listrik 60 watt yang dapat diturun-naikkan temperaturnya sesuai dengan keperluan; (8) blok paraffin dipotong dengan mikrofon untuk pembuatan preparat; (9) Meletakkan sejumlah coupes pada kaca benda yang telah diberikan perekat menggunakan mayers albumen, lalu ditetesi aquades secukupnya; (10) staning yaitu dilakukan deparaffinasi dan dilanjutkan pewarnaan Haematoksylin-Eosin.

Teknik pengumpulan data untuk preparat hepar yang kerusakan batas sel diperoleh dengan cara membagi 1 lobulus yang di dalamnya terdapat vena sentralis menjadi 4 bagian yaitu atas, kanan, bawah, dan kiri. Selanjutnya menentukan 5 lamina (lempeng) yang didalamnya terdapat sel-sel hati pada ke empat bagian tersebut, kemudian menentukan 5 sel hati didalam 1 bagian lamina yang telah ditentukan, sehigga 1 lobulus dengan 1 vena sentralis ditengahnya akan diperoleh 100 sel hati yang diamati kerusakan batas selnya. Data infiltrasi sel lemak diperoleh dengan menggunakan cara yang sama dengan pengumpulan data kerusakan batas sel yaitu dengan cara membagi lobulus menjadi 4 bagian, kemudian menentukan 25 sel pada masing-masing bagian lobulus tersebut, sehingga setiap 1 lobulus terdapat 100 sel yang diamati. Infiltrasi sel lemak ditandai dengan adanya tetes-tetes yang besar sehingga mendesak nukleus kearah tepi atau hanya tampak sebagai tetes lemak yang kecil dalam hepatosit. Pengumpulan data kerusakan endotel jantung dengan cara mengamati ada tidaknya kerusakan endotel arteri atau aorta. Pengumpulan data infiltrasi sel lemak pada jantung dengan cara mengamati ada tidaknya bulatan atau tetes-tetes transparan.

Pengumpulan data untuk kerusakan endotel dan infiltrasi sel digunakan chek-list dengan coding untuk "ya" adalah 1 dan 0 untuk jawaban "tidak", "Ya" bila sesuai dengan pernyataan pada chek-list yaitu adanya kerusakan endotel atau infiltrasi sel lemak dan "Tidak" untuk sebaliknya.

Analisis data dilakukan dengan statistic deskriptif. Hal ini karena skor-skor yang ada pada penelitian aorta dan arteria koronaria jelas tidak homogen. Sedangkan hasil rata-rata sel nekrosis dan infiltrasi lemak pada hati menunjukkan standar deviasi besar sehingga tidak bisa dilakukan uji statistic parametric. Uji beda non parametric juga tidak dilakukan karena ada sel-sel yang kosong pada tabulasi silangnya.

\section{Hasil dan Pembahasan}

\section{Data hepar}

1. Perlemakan hepar

Profil perlemakan hepar disajikan pada Gambar 1. Perlemakan hepar paling tinggi pada perlakuan 2 dan paling rendah pada normal. Perlemakan pada perlakuan 2 lebih tinggi daripada 1. Hal ini kemungkinan disebabkan pemberian sari buah salak belum optimal dosisnya dan belum tepat lama waktunya.

Gambaran histopatologi perlemakan hepar dapat dilihat pada Gambar 2. 


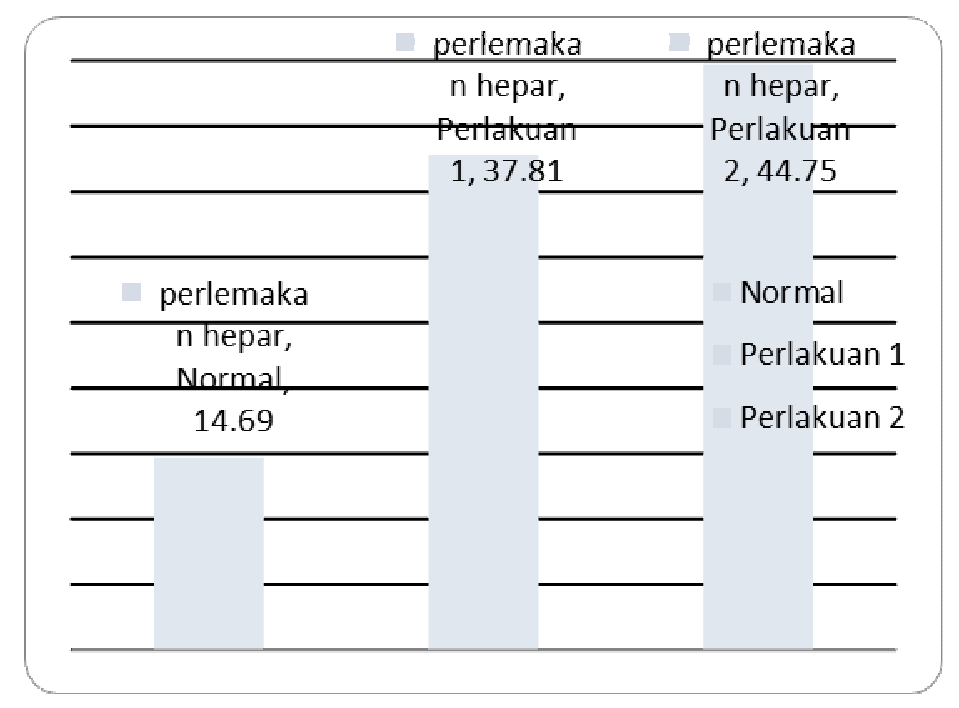

Gambar 1. Data perlemakan hepar dengan variasi perlakuan

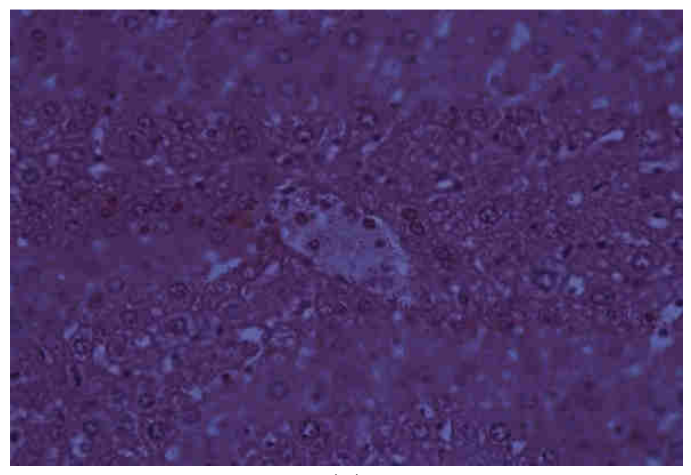

(a)

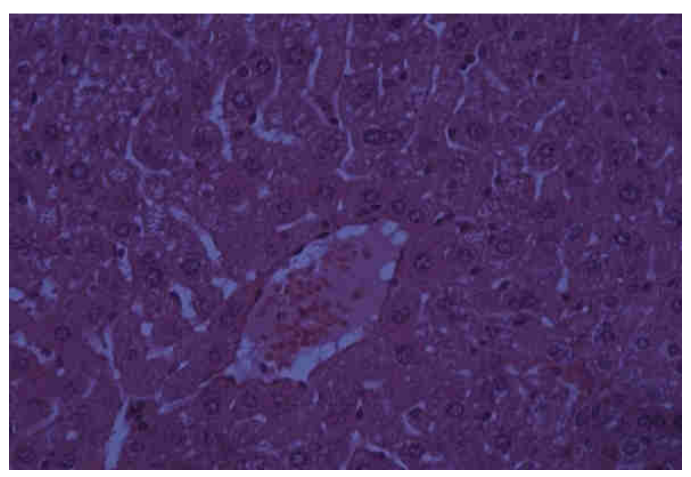

(b)

Gambar 2 Perlemakan lemak pada sel hepar yang menunjukkan gambaran (a) sinusoid hati dan (b) vena centralis

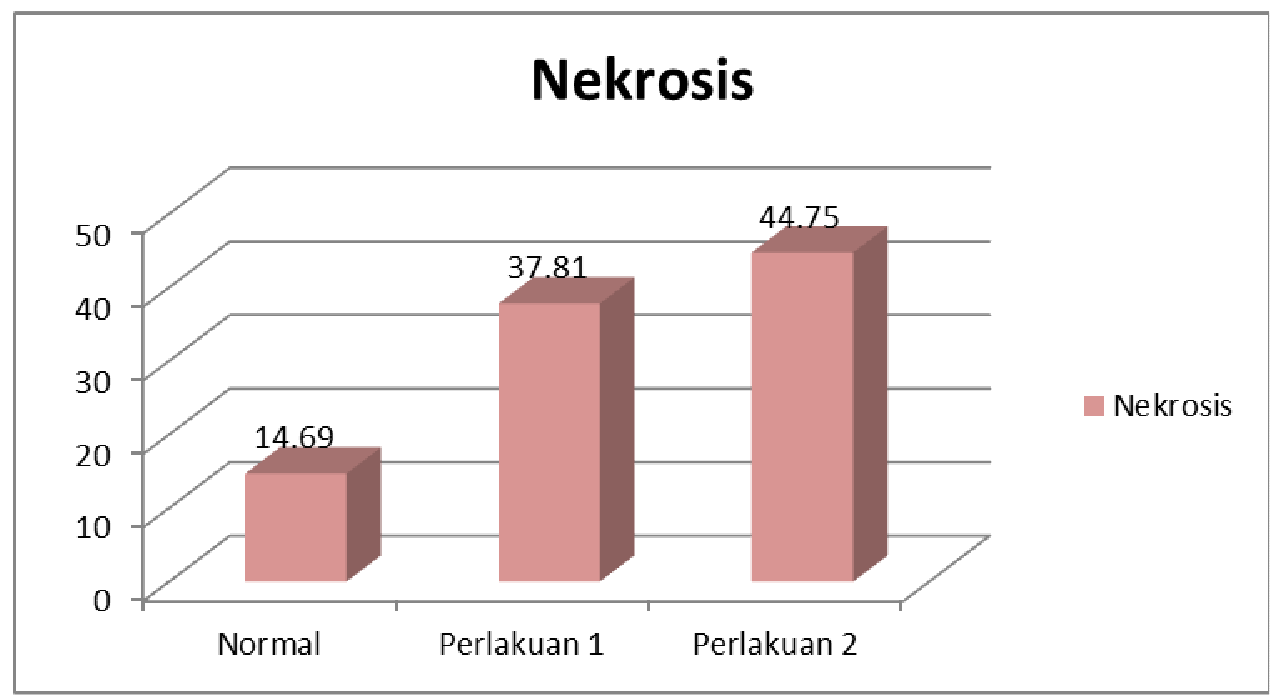

Gambar 3 Profil nekrosis hepar pada berbagai perlakuan 
2. Nekrosis pada hepar

Profil nekrosis hati pada variasi perlakuan ditampilkan pada Gambar 3, sedangkan gambaran histopatologinya dapat dilihat pada Gambar 4. Nekrosis sel hepar paling tinggi pada perlakuan 2 dan paling rendah pada normal. Nekrosis pada perlakuan 2 lebih tinggi daripada 1. Hal ini kemungkinan disebabkan pemberian sari buah salak belum optimal dosisnya dan belum tepat lama waktunya.

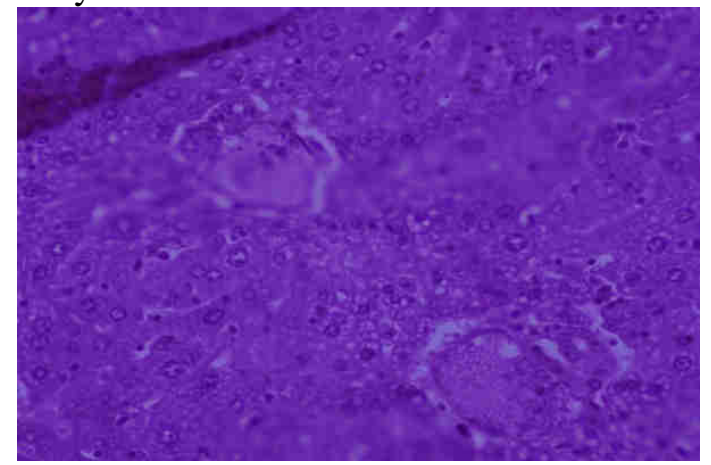

Gambar 4. Struktur histopatologi nekrosis hati

Pemeriksaan histologi pada preparat hati yang mengalami kerusakan menunjukkan beberapa perubahan. Perubahan tersebut Nampak pada struktur histopatologi berupa degenerasi sel berupa penimbubnan lemak dan nekrosis. Pengamatan struktur histopatologi pada preparat penelitian ini meliputi nekrosis dan penimbunan/infitrasi lemak.

Lemak akan terlihat dalam lemak sel menunjukkan terjadinya proses degenerasi. Degenerasi perlemakan adalah suatu keadaan yang terlihat pada sel yang mengalami tetes-tetes yang besar sehingga mendesak nucleus kearahtepi atau hanya tampak sebagai tetes lemak yang kecil dalam hepatosit. Nekrosis koagulatif bisa terjadi dari degenerasi hyaline yang ditandai oleh kelompok bulatan-bulatan yang terlihat risin bila dicat dengan $\mathrm{H}$ Ematoxyllin Eosin (HE) senyawa-senyawa protein fusfolipida menyususn bulatan-bulatan ini.

Nekrosis sel yang terjadi akan nampak dalam gambaran histologi berupa proses menghilangnya inti. Proses perubahan tersebut terdiri dari tahap proses piknosis, karioseksis dan kariolisis. Pengerutan inti terjadi pada proses piknosis, yang diikuti dengan perubahan inti dari struktur retikula menjadi gelap merata. Tanda karioseksis terjadi berupa fragmentasi isi sel inti dan kemudian terdispasi ke dalam sitoplasma. Terjadinya kariolisis dapat diketahui dengan munculnya tanda berupa inti secara lengkap menghilang bersamasama kromatin.
Non alcoholic Fatty liver Disease (NAFDL) menyebabkan akumulasi steatosis dalam hati yang terjadi bukan karena konsumsi alkohol. Prevalensinya diatas $30 \%$ di negara maju dan mendekati $10 \%$ di negara berkembang, sehingga sangat besar diseluruh dunia. Patogenesis NAFDL berhubungan dengan resistensi insulin dan sering ditemukan pada orang gemuk sentral atau diabetes. Resistensi insulin dan kelebihan lemak dihubungkan dengan peningkatan penimbunan lemak di hati (Smith \& Adams, 2011: 97-113).

NAFDL sering menutupi kondisi steatosis sederhana yang relatif jinak dan nonalcoholic steatohepatitis (NASH). NASH ditandai dengan penyakit hepar yang kronis dan progresif yang bisa berlanjut sebagai sirrosis dan tahap akhir penyakit hepar dan carcinoma hepar (hepatoma). Untuk mencegah terjadinya penyakit ini adalah dengan menghindari obesitas, hiperlipid, diabetes tipe 2 dan mengatur pola hidup supaya berat badan turun serta olahraga (Basaranoglu dan Ormece, 2014: 127-132). Penyakit-penyakit diatas karena hiperlipidemia dan terjadi perlemakan hati sehingga salak harus diteliti lebih lanjut sampai bisa terbukti mencegah penyakit-penyakit tersebut. Penelitian ini merupakan penelitian awal, bisa dilanjutkan dengan penelitian yang lain dan teliti pada tikus sehingga bisa dipakai sebagai data dasar untuk penelitian pada manusia.

\section{Aorta dan Pembuluh Darah Koronaria}

\section{Kerusakan endotel}

Gambar 5 menunjukkan kerusakan endotel pada aorta. Kelompok kontrol pada penelitian ini ditemukan seluruh endotel aorta (gambar 10) dan pembuluh darah koroner dalam keadaan tidak rusak.

Kelompok perlakuan 1 menyebabkan 50\% endotel aorta rusak berat dan $96,67 \%$ endotel pembuluh darah koronaria rusak. Kerusakan endotel pembuluh darah koronaria terdiri dari rusak ringan 26,67\%; rusak sedang 26,67\%; rusak berat $50 \%$ dan rusak total $13,33 \%$. Kelompok ini mendapat diet lemak. Hal ini sesuai dengan pendapat Mark, dkk. (2000:523) yang menyebutkan terjadinya cedera di sel endotel akan mengawali aterosklerosis. Cidera yang terjadi bisa secara mekanis maupun karena aadanya bahanbahan sitotoksis. Bahan tersebut bisa dengan LDL yang teroksidasi.

Kelompok ini tidak mengalami kerusakan endotel semua pembuluh darahnya, karena belum ada pemicu aterosklerosis berupa diet lemak. Endotel pembuluh kelompok perlakuan 2 
menunjukkan hasil $97,71 \%$ endotel aorta rusak dan 93,33\% endotel arteri koroneria mengalami kerusakan. Kerusakan endotel aorta pada kelompok perlakuan 2 memang lebih besar daripada kelompok perlakuan 1, tetapi sebagian besar kerusakan endotel aorta hanya ringan dan sedang yaitu sebesar $28,57 \%$ dan $42,86 \%$ (dijumlah jadi $71,43 \%$ ). Kerusakan endotel aorta pada kelompok perlakuan 1 memang hanya $50 \%$ tetapi semuanya pada tahap rusak berat.

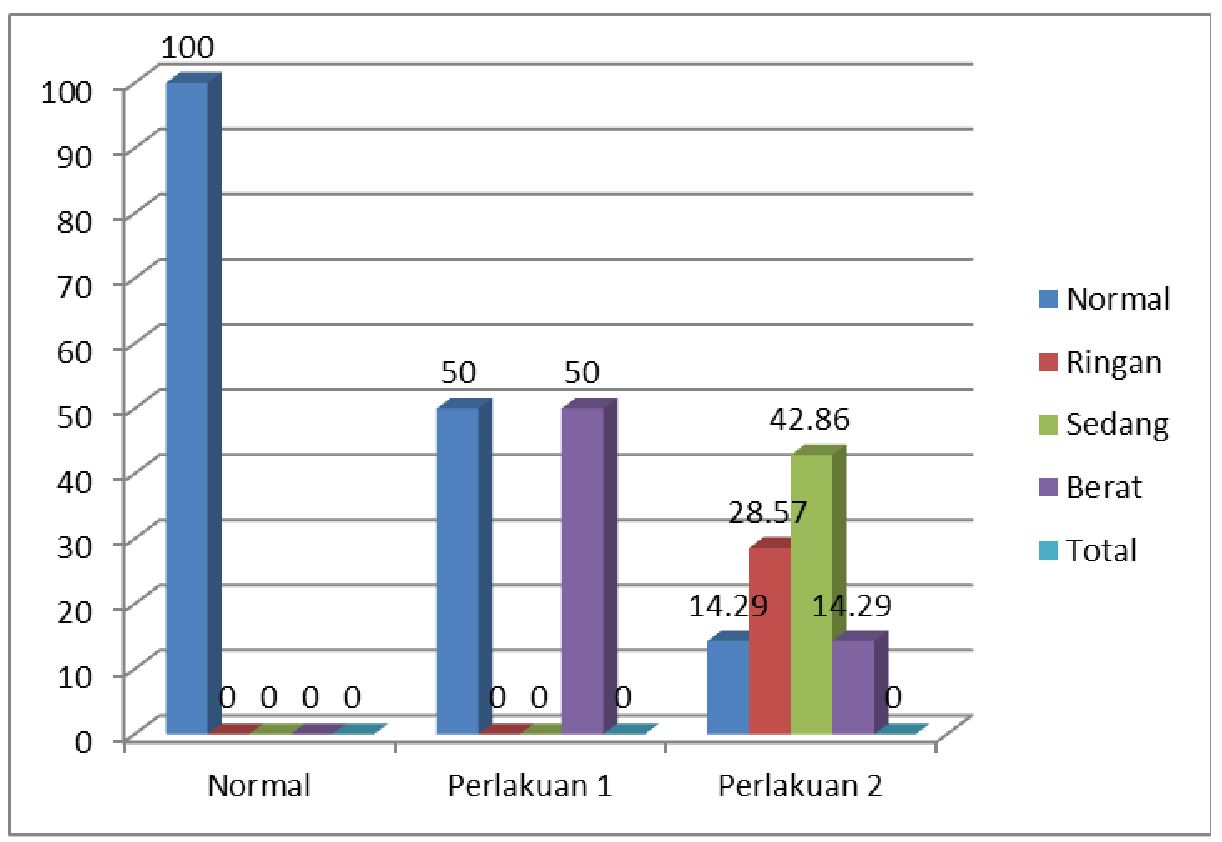

Gambar 5 Profil kerusakan endotel pada aorta

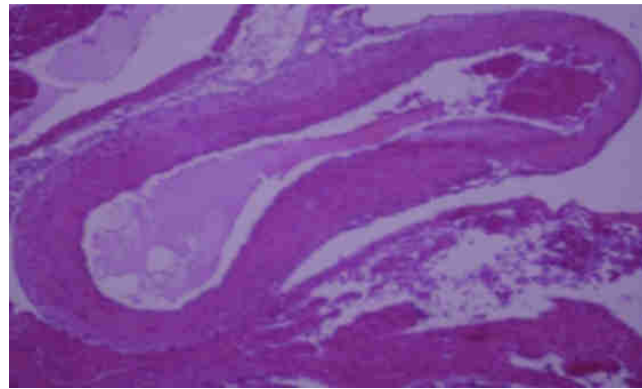

a

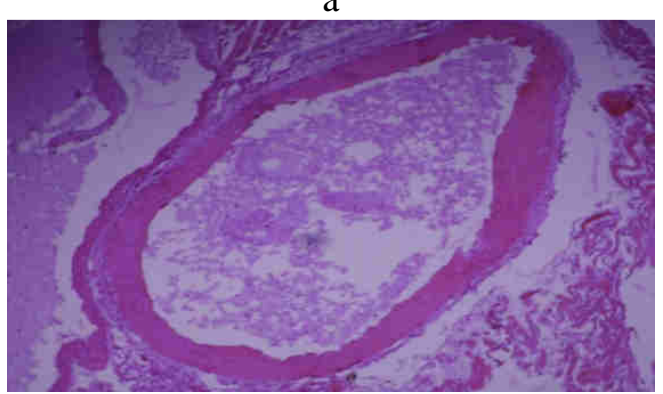

C

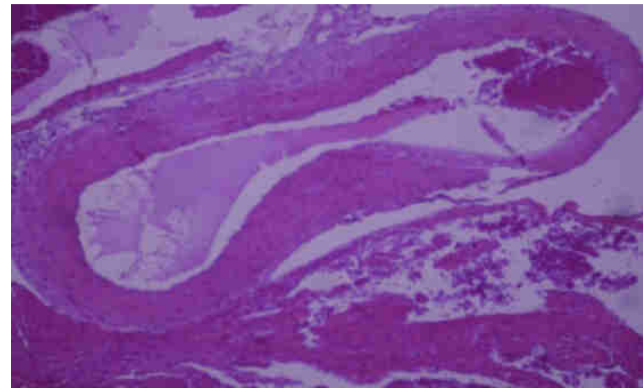

B

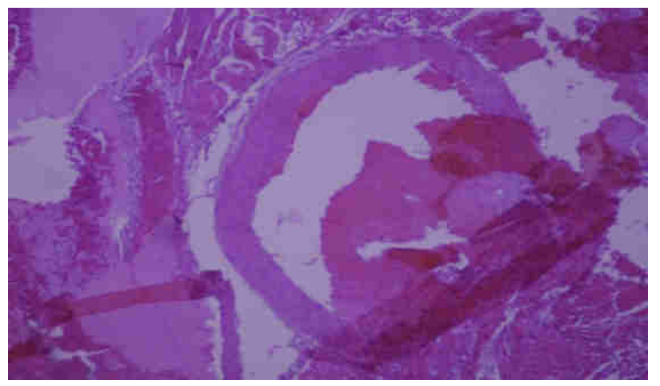

$\mathrm{D}$ 


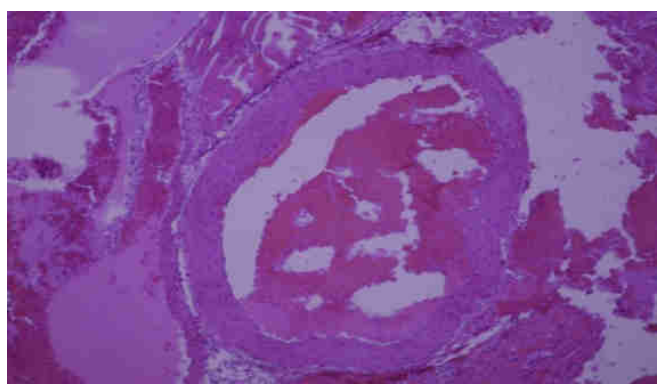

Gambar 6 Struktur histopatologi kerusakan endotel aorta (a) normal (b) 25\% ringan (c) 25-50\% sedang (d) $50-75 \%$ berat (e) $>75 \%$ total

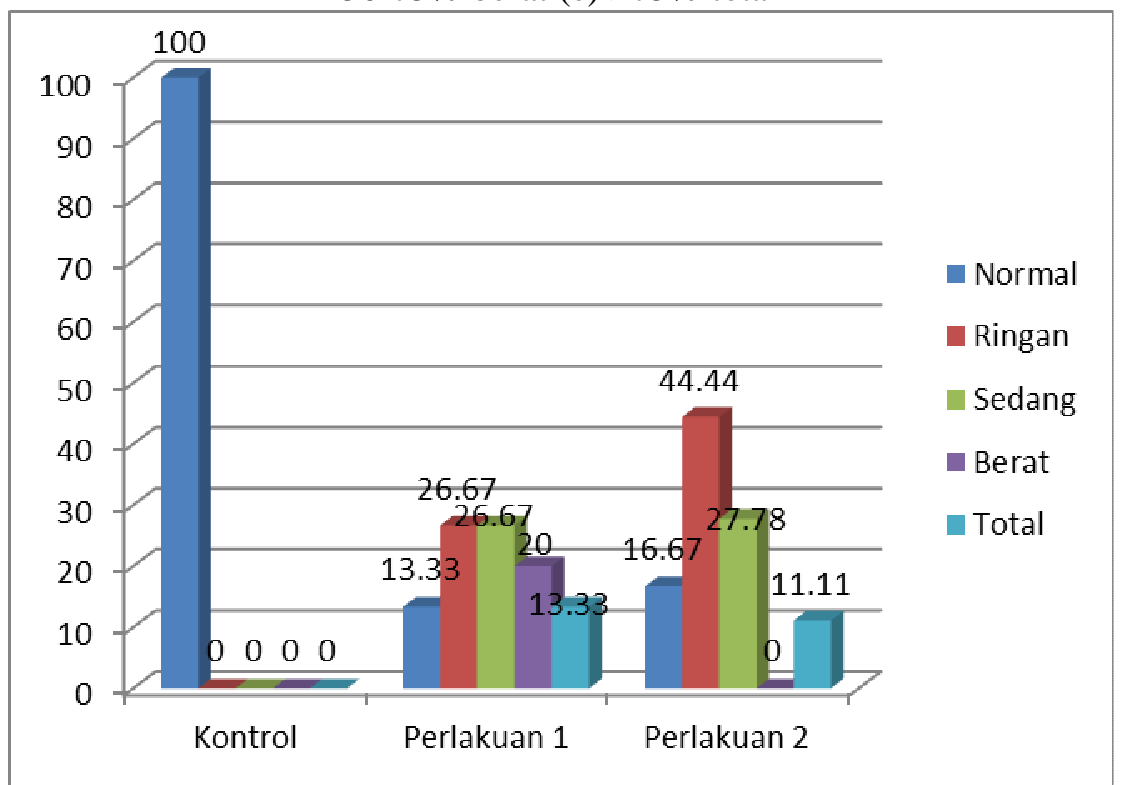

Gambar 7 Profil kerusakan endotel pada arteri koronaria



a

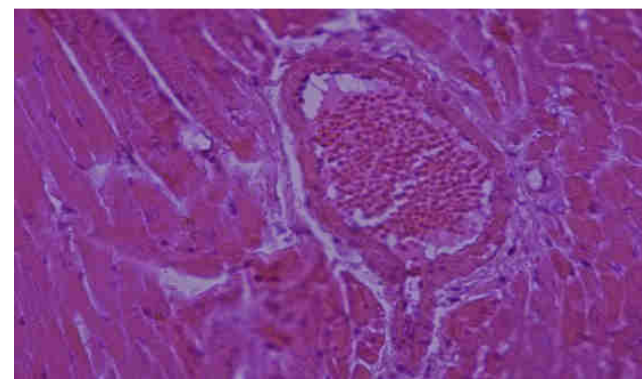

C

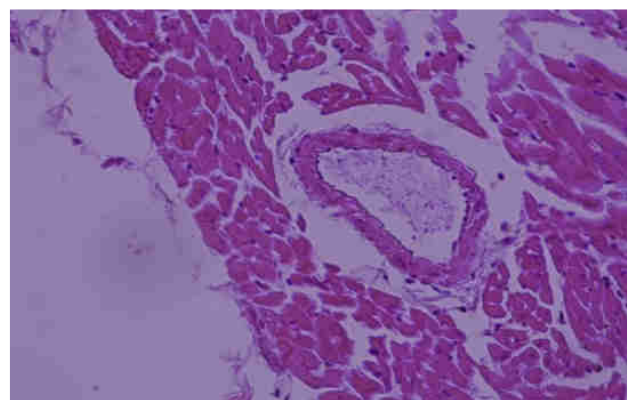

B

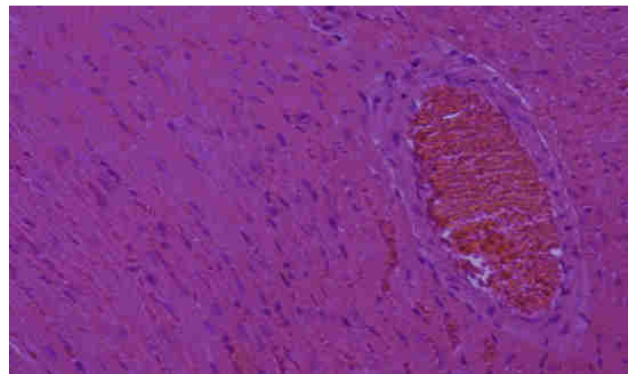

$\mathrm{D}$ 


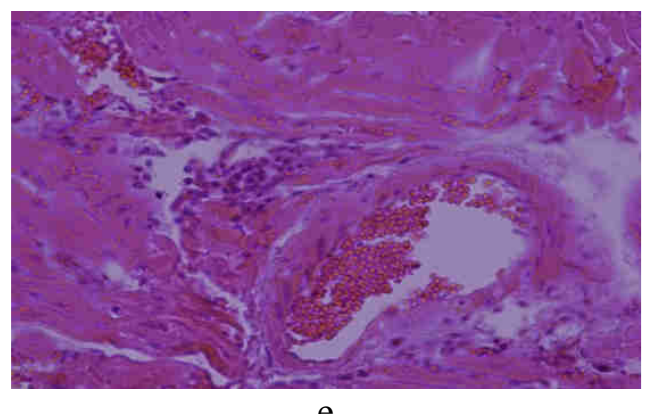

Gambar 8 Struktur histopatologi kerusakan endotel arteri koronaria (a) normal (b) 25\% ringan (c) 25-50\% sedang (d) $50-75 \%$ berat (e) $>75 \%$ total

Data kelompok perlakuan 2 pada kerusakan endotel arteria koroneria secara total hampir sama dengan kelompok perlakuan 1, tetapi sebagian besar keolmpok perlakuan 2 hanya rusak sedang $(27,28 \%)$. Sebagian besar kerusakan endotel pada arteria koroneria pada perlakuan 1 berupa tingkat kerusakan berat dan total yaitu $20 \%$ dan $13,11 \%$, sedangkan pada perlakuan 2 yang rusak total hanya 11,11\% (Gambar 7 dan Gambar 8).

Kondisi diatas sesuai dengan teori timbulnya aterosklerosis yang biasanya dikaitkan dengan kadar lemak darah. Kadar lemak dalam darah (terutama kolestrol) yang meningkat maka risiko untuk terjadi aterosklerosis menjadi tinggi.

Menurut Simorangkir dalam Bunga Citraningrum (2010: 52) konsumsi makanan yang mengandung lemak dan kolesterol tinggi memicu peningkatan kolestrol dalam darah. Kondisi tersebut disebut hiperkolesterolemia. Hiperkolesterolemia merupakan salah satu penyebab obstruksi/penyumbatan pembuluh darah. Hal ini terjadi karena hiperkolesterolemia secara perlahan akan menimbulkan penimbunan kolestrol pada dinding arteri, sehingga terjadi proses aterosklerosis. Kolestrol yang berlebihan dalam darah akan melekat pada dinding pembuluh darah, selanjutnya LDL akan menembus dinding pembuluh darah melalui sel endotel, masuk ke lapisan pembuluh darah berupa tunika intima, sehingga bisa dilihat sebagai kerusakan sel andotel.

\section{Infiltrasi sel lemak}

Infiltrasi lemak pada aorta tidak terjadi pada kelompok kontrol, jadi 100\% normal. Kelompok perlakuan 1 menyebabkan semua (100\%) preparat aorta menunjukkan infiltrasi sel lemak sedang. Preparat kelompok perlakuan 2 hanya menunjukkan infiltrasi sel lemak $57,15 \%$ dan
42,86\% hanya merupakan infiltrasi ringan (Gambar 8)

Infiltrasi sel lemak pada arteria koronaria tidak terjadi pada $70 \%$ kelompok kontrol dan infiltrasi lemak yang terjadi pada kelompok ini hanya tingkat ringan dan sedang yaitu sebesar $20 \%$ dan $10 \%$ saja. Kelompok perlakuan 2 paling tinggi infiltrasi lemaknya yaitu 96,67\% dan paling banyak infiltrasi lemak total yaitu sebesar 33,33\%. Kelompok perlakuan 2 hanya terinfiltrasi lemak sebesar 55,56\% dan sebagian besar hanya infiltrasi ringan $(16,67 \%)$ dan sedang $(22,22 \%)$.

Kondisi kerusakan endotel dan infiltrasi lemak pada aorta dan arteri terjadi karena kondisi hiperlepidemia yang dibuat dengan pemberian diet lemak hewan. Makanan tersebut terdiri dari $500 \mathrm{gr}$ BR II, $20 \mathrm{ml}$ kuning telur bebek dan $60 \mathrm{ml}$ minyak babi, sehingga didapatkan perbandingan 24:1:3. Komposisi tersbut didapatlkan dengan penelitian pendahuluan sehingga didapatkan bahan makanan yang disukai tikus dengan melihat selera makanannya terhadap pakan tersebut serta sisa pakan yang tidak dimakan hewan uji tersbu=ut. Menurut Rumanoff dan Rumanof (bunga Citraningrum, 2010: 51) dalam telur bebek bagian kuning terdapat 47,0 gr air; 17,0 gr protein; 35,0 gr lemak; 0,8 gr karbohidrat; 398 kkalori; $150 \mathrm{mg}$ kalsium, $400 \mathrm{mg}$ fosfor, 7,0 mg besi; $2870 \mathrm{sl}$ vit A; $0,60 \mathrm{mg}$ vit B1. Sedangkan putih telur bebek mengandung 88,0 gr air; 11,0 gr protein; 0 gr lemak; 0,8 gr karbohidrat; 54 kkalori; $21 \mathrm{mg}$ kalsium; $20 \mathrm{mg}$ fosfor; $0,1 \mathrm{mg}$ besi; $0,01 \mathrm{mg}$ vit B1. Menurut Bharata (2005: 45) minyak atau lemak mengandung 902 kkalori dan 100 gr lemak.

Masyarakat Indonesia sering menggunakan bahan-bahan lokal untuk pencegahan dan pengobatan suatu penyakit secara tradisional. Pencegahan penyakit degeneratif sering memanfaatkan buah salak sebagai salah satu 


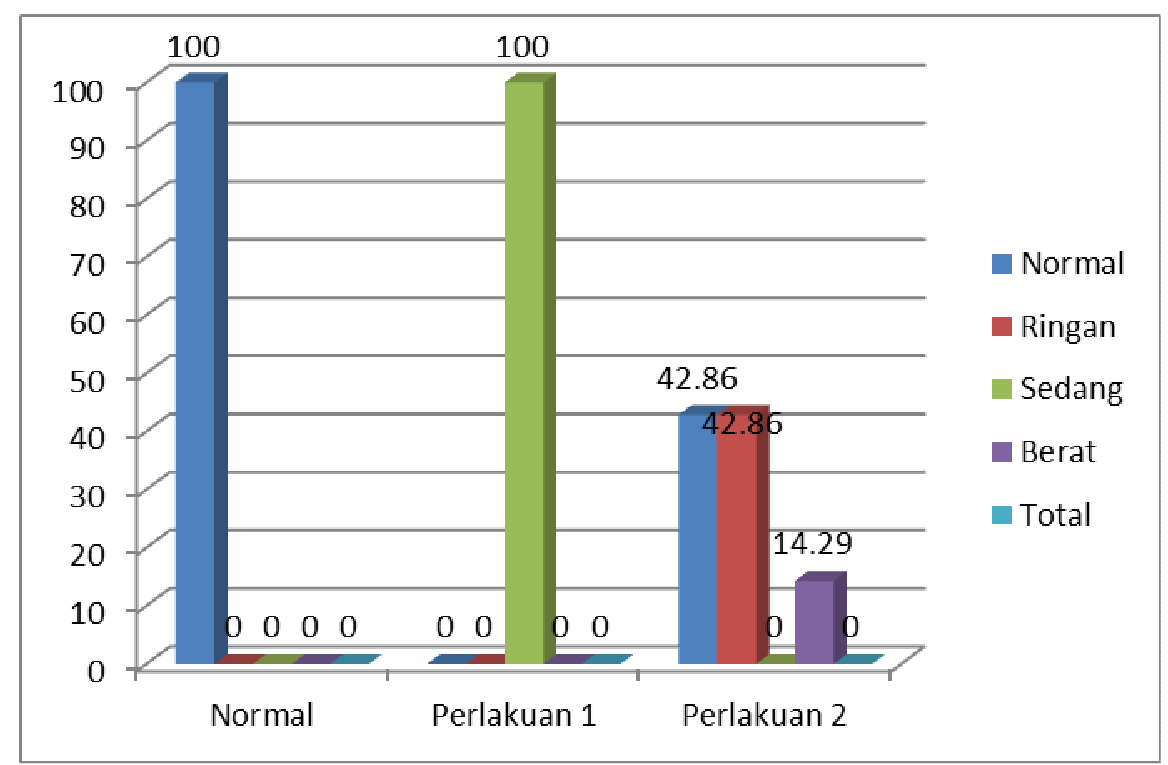

Gambar 5 Profil infiltrasi lemak pada aorta

sumber daya alam yang melimpah di Sleman. Cara tersebut sesuai dengan prinsip pencegahan penyakit degeneratif yaitu dengan cara menjaga pola makan dengan mengurangi makanan yang berlemak tinggi dan memperbanyak makanan yang berserat tinggi.

Data pada perlakuan kelompok 2 yang menunjukkan kecenderungan penurunan kerusakan endotel dan infiltrasi lemak pada aorta dan arteri dibandingkan yang terjadi pada perlakuan 1 merupakan bukti bahwa struktur histopatologi pembuluh darah jantung yang diberi lemak hewani dan salah sari buah sebagian mengalami proses terjadinya aterosklerosis dalam jumlah yang lebih sedikit dibandingkan pada pembuluh darah jantung hewan uji dengan perlakuan 1 yang hanya diberi diet lemak hewani.

Kandungan vitamin $\mathrm{C}$ yang tinggi pada salak yaitu sebesar 2,00 per 100 gr merupakan alasan yang mendasari pemilihan buah ini sebagai alternatif bahan alam utuk menurunkan kolestrol darah.

Mekanisme pemecahan kolestrol menjadi asam empedu dan garam empedu oleh vitamin $\mathrm{C}$ tidak terkait langsung melainkan hanya berperan sebagai kofaktor bagi enzim pemecah kolestrol di dalam hati (Hertog, 1992: 151) . vitamin C yang di berikan akan menurunkan kadar kolestrol darah dengan cara membantu memecah kolestrol menjadi asam empedu (asam kholat dan asam kenokdeoksalat).
Asam empedu disintesis oleh hati dan disekresikan melalui kantong empedu ke dalam lumen usus, kemudian menghasilkan senyawa emfipatik atau sering disebut garam empedu. Garam empedu bertugas sebagai detergen, yaitu memecah lemak menjadi bentuk yang lebih kecil dan mengabsorbsi lemak. Sintesis asam empedu yang terjadi di hati menjadi garam empedu yang kemudian mensekresikan ke usus dan dikeluarkan dari tubuh melalui feses. Semakin banyak kolestrol dari tubuh yang dieliminir dari usus melalui feses dalam bentuk asam empedu dan garam, maka kolestrol di dalam darah akan menurun (Sitepoe, 1992: 101).

Vitamin C juga berperan sebagai oksidan. Vitamin $\mathrm{C}$ yang diberikan pada mencit dapat mencegah terjadinya peninggian sel-sel endotel tunika intima arteri sebagai gejala awal arterosklerosis dan menjadikan normalnya keadaan pembuluh darah arteri koronaria. Vitamin C sebagai vitamin antioksidan dapat mencegah terjadinya atherosclerosis. Vitamin $\mathrm{C}$ bersamasama dengan darah akan bereaksi dengan radikan bebas sebagai produk oksidasi LDL, sehingga menyebabkan LDL kurang aterogenik dan oksidasi LDL terhambat. Terhambatnya oksidasi LDL maka tidak terjadi penimbunan kolestrol di dinding arteri tersebut sehingga tidak terjadi keradangan dan proliserasi sel-sel otot polos dan hal itu menjadikan tetap normal sebagai vitamin antioksidan berperan dalam menghambat terjadinya oksidasi senyawa lemak (Satoto, 1998: 298). 
Penurunan kolestrol dalam darah mencit disebabkan juga oleh kandungan serat kasar dalam salak yang cukup tinggi. Serat dalam makanan terdiri atas dua komponen utama, yaitu larut dan tak larut. Serat mempunyai fungsi metabolisme zat gizi yang penting, walaupun tidak dapat dicerna oleh tubuh. Serat kasar tidak dapat dicerna maka tubuh hanya bisa sedikit menghasilkan glukosa dan mengakibatkan penurunan jumlah asam piruvat, dan secara tidak langsung jumlah Asetil Co-A dalam tubuh menurun karena asam piruvat merupakan pembentuk Asetil Co-A. apabila Asetil Co-A dalam tubuh menurun maka proses sintesis kolestrol juga ikut terganggu, sehingga kadar kolestrol dalam darah menurun, karena Asetil Co-A berfungsi sebagai prekursor sintesis kolestrol. Serat kasar dapat menurunkan kadar kolestrol dalam plasama, dimungkinkan mengikat kolestrol dan asam empedu yang ada dalam usus terjadi ikatan intraluminal antara serat, kolestrol dan asam empedua yang kemudian dikeluarkan melalui feses, keadaan ini akan mengurangi sirkulasi enterohepatik asam empedu dan meningkatkan perubahan kolestrol menjadi asam empedu sehingga kolestrol plasma menurun (Potter, 1979: 233). Kondisi kadar kolestrol hewan uji pad perlakuan 2 yang menurun akibat tambahan konsumsi buah salak menyebabkan kerusakan endotel pembuluh darah dan sel hepar serta infiltrasi lemak pada pembuluh darah dan sel hepar juga menurun.

Zat aktif flavanoida menurunkan kadar kolestrol dalam darah yang ada pada flavanoida adalah iso-flavon. Dalam perlakuan pemberian diet lemak hewani yang diimbangi pemberian sari buah salak, kadar kolestrol darah mencit mengalami penurunan. Dalam sintesis kolestrol dalam darah Asetil Co-A merupakan prekursor. Iso-flavon diduga mampu mengahambat enzim untuk sintesis asam lemak dalam hati. Iso-flavon kemungkinan dapat menghambat enzim HMG Co-A Reduktase. Enzim HMG Co-A reduktase merupakan enzim utama dalam sintesis kolestrol. Enzim ini berperan dalam proses esterefikasi kolestrol, yaitu sebelum kolestrol diserap dan diubah menjadi kilomikron dalam usus (Winarsi, 2005: 50). HMG Co-A menjadi mevalonat, bila jumlah kolestrol tinggi maka sintesis kolestrol hati akan menurun. Penghambatan umpan balik pembentuk kolestrol mungkin dengan pengaturan produksi enzim HMG Co-A reduktase. Kolestrol diabsorbsi dari diet menghambat jalur biosintetik hepar dengan menurunkan sintesis pada reaksi HMG Co-A reduktase (Titik Ismiyati, 1999: 79)
Isoflavon juga memiliki aktifitas antioksidan karena adanya gugus hidroksil fenolit, ketika senyawa ini bereaksi dengan radikal bebas maka reaksi berantai radikal bebas akan dihambat oleh efek resonansi inti aromatik. Mekanisme kerja isoflavon melalui mekanisme perbaikan profil lipid, yaitu menurunkan kolestrol total, LDL dan trigliserida serta meningkatkan HDL. Mekanisme lain penurunan kolestrol oleh iso-flavon adalah peningkatan sekresi asam empedu dan penurunan metabolism kolestrol. Efek dari kardoprotektif isoflavon juga melalui penurunan agregasi platelet (trombosit) dan terbentuknya gumpalan, serta penghambatan atherosklerosis, baik oleh kerja antioksidan maupun dengan cara menghambat proliferasi dan adesi sel-sel dalam arteri.

Flavanoida bekerja melindungi pembuluh darah agar tidak mudah terjadinya ateroma yaitu dengan cara, menghambat poliferasi sel-sel otot polos, meningkatkan fungsi sel endotel, baik dalam pertumbuhan maupun perbaikan dan mencegah terjadinya inflamasi. Iso-flavon tidak mengandung kolestrol, oleh karenanya berefek meningkatkan ekskresi asam empedu, dan mengubah kecepatan sintesis kolestrol hepatik. Melalui mekanisme seperti ini pula, diduga iso-flavon memberikan efek proteksi terhadap serangan LDL teroksidasi. Kondisi ini berhubungan dengan potensi antioksidan iso-flavon yang mampu mencegah LDL teroksidasi, dan mempertahankan kerja sistem vaskuler (Winarsi, 2005: 50-53).

\section{Simpulan}

Berdasarkan hasil penelitian yang telah dilakukan, maka dapat dibuat simpulan sebagai berikut: Struktur histopatologi pembuluh darah jantung mencit yang diberi sari buah (Salacca edulis, R) dan diet lemak hewani mengalami kerusakan endotel dan infiltrasi lemak lebih kecil dibandingkan struktur histopatologi pembuluh darah jantung pada mencit yang diberi tambahan diet lemak.

Struktur histopatologi sel hepar mencit yang diberi sari buah salak (Salacca edulis, R) dan diet lemak hewani mengalami kerusakan endotel dan infiltrasi lemak lebih banyak dibandingkan struktur histopatologi sel hepar pada mencit yang diberi tambahan diet lemak.

\section{Pustaka}

Agus Suryanto. 1994. Pengaruh Ekstrak Biji Termemer (Luffa acutangula, Roxb.) 
terhadap Struktur Mikroanatomi Hepar Mencit (Mus musculus, L) setelah Perlakuan dengan Sodium Siklamat. Skripsi. Yogyakarta: Fakultas Biologi UGM.

Ali Khomsan. 2004. Pangan dan Gizi untuk Kesehatan. Jakarta: PT. Raja Grafindo Persada.

Astawan Made. 2008. Seri Kesehatan Keluarga Sehat dengan Buah. Jakarta: Dian Rakyat.

Bunga Citraningrum. 2010. Pengaruh Pemberian Ekstrak buah Salak (Salacca edulis, R) pada Lipid Darah Mencit yang Diberi Diet Lemak. Skripsi. FMIPA. UNY: Yogyakarta.

Bharata. 2005. Komposisi Bahan Makanan. Yogyakarta: Bhatara.

Deddy Muchtadi. 1993. Metabolisme Zat Gizi. Jakarta: pustaka Sinar Harapan.

Dellmann, H.D dan Brown, E.M. 1992. Buku Teks Histologi Veteriner II. Edisi 3. (Alih bahasa: R. hartono). Jakarta: UI press.

Denny Santoso. 2000. Makan Sehat Hidup Sehat. Yogyakarta: Kompas.

Dwi Rita Anggraini. 2008. Gambaran Makroskopis dan Mikroskopis Hati dan Ginjal Mencit akibat Pemberian Plumbum Asetat. Tesis. Medan: Universitas Sumatera Utara.

Faisal Yatim. 2000. Waspadai Jantung Koroner, Stroke, Meninggal Mendadak Atasi dengan Pola Hidup Sehat. Jakarta: Yayasan Obor Indonesia.

Femi Dwi Aldini. 2010. Laporan Akhir PKM-P Studi Efek Samping Penggunaan UndurUndur Darat (Myrmeleon sp) sebagai Obat Antidiabetik pada Tikus Putih Jantan(Rattus norvegicus). Surakarta: Universitas Sebelas Maret.

Gardjito, dkk. 1992. Pengantar Ilmu Pangan Nutrisi dan Mikrobiologi. Yogyakarta: Universitas Gajah Mada Press.

Guyton and Hall. 1996. Fisiologi Kedokeran. Jakarta: EGC.

Handoko, Ari. 2009. Obat Hipertensi Dengan Mentimun. Diakses selasa 25 Mei 2011 pukul 09.00 WIB di akses dari alamat situs: http://mig33sukabumi.forumotion.

Harper, H. A., Rodwell, V. W., and Mayes P. A. 2001. Harper's Biochemistry. Jakarta: EGC.

Heyne, K. 1987. Tumbuhan Berguna Indonesia. Jakarta: Yayasan Sarana Wana Jaya.

Hull, Alison. 1996. Penyakit Jantung Hipertensi dan Nutrisi. Jakarta: Bumi Aksara

Imam Soeharto. 2000. Pencegahan \& Penyembuhan Penyakit Jantung Koroner. Jakarta: Gramedia Pustaka Utama
John B. Smith B. V. Sc. 1988. Pemeliharaan Pembiakan dan Penggunaan Hewan Percobaan Di Daerah Tropis. Jakarta: UI Press.

Jordan, Akhmad. 2010. Aneka Buah dan Khasiatnya. Yogyakarta: Aulia Publishing.

Junqueira, L. C; Carneiro, J dan Kelley, R.O. 1997. Histologi Dasar. Edisi 8. (Alih bahasa: Jan Tambayong). Jakarta: EGC

Lesson, C. Roland, Lesson, T.S dan Paparo, A.A. 1996. Buku Teks Histologi. Edisi 5. (Alih bahasa: Yan Tambayong). Jakarta: EGC.

Linder, M. C. 1992. Biokimia Nutrisi dan Metabolisme dengan Pemkaian Secara Klinis. Jakarta: UI Press.

Mariano. 1996. Atlas Histologi Manusia. (Terjemahan oleh Moh. Martoprawiro). Jakarta: EGC penerbit Buku Kedokteran.

Muttaqin, Arif. 2009. Asuhan Keperawatan Klien dengan Gangguan Sistem Kardiovasvaskuler dan Hematologi. Jakarta: Salemba Medika.

Povey, R. 1999. Memantau Kadar Kolesterol Anda. Jakarta: Penerbit Arcan.

Price, S.A dan Wilson, L.M. 1994. Patofisiologi Konsep Klinis Proses-Proses Penyakit. Buku pertama. Edisi 4. (Alih Bahasa: Peter Anugerah). Jakarta: EGC.

Ramadhan, A. J. 2010. Mencermati Berbagai Gangguan Pada Darah dan Pembuluh Darah. Yogyakarta: DIVA Press

Ruhyana. 2007. Hipertensi penyebab utama penyakit jantung. Alamat situs: http://ruhyana.wordpress.com.

Santoso, H. B dan Nurliani, A. 2006. Efek Doksisiklin Selama Masa Organogenesis pada Struktur Histologi Organ Hati dan Ginjal Fetus Mencit. Bioscientiae. Volume 3, Nomor 1. Halaman 15-27.

Sediaoetama dan Achmad Djaelani. 2008. Ilmu Gizi untuk Mahasiswa dan Profesi. Jakarta: Dian Rakyat.

Setiawan Dalmartha. 1999. Atlas Tumbuhan Obat. Jakarta: Niaga Swadaya.

Sitepoe, Mangku. 1993. Kolesterol Fobia Keterkaitannya dengan Penyakit Jantung. Jakarta: Gramedia Pustaka Utama

Sitepoe, Mangku. 1997. Penyakit Jantung dan Usaha Pencegahannya. Jakarta: Gramedia Pustaka Utama.

Smith \& Adams. 2011. Non-alcoholic fatty liver disease. Critical Reviews in Clinical Laboratort Sciences, 48:3, 97-113.

Soewolo, dkk. 2005. Fisiologi Manusia. Malang: Universitas Negeri Malang 
Sumeru Ashari. 1995. Hortikultura Aspek Budaya. Jakarta: UI-Press

Swarth, Judith. 2006. Stres dan Nutrisi (Terjemahan oleh dr. Irawan). Jakarta: Bumu Aksara.

Ward, Jeremy. et al. 2009. At a Glance FISIOLOGI. Jakarta : Erlangga

Warisno. 2001. Membuat Telur Asin Aneka Rasa. Jakarta: Gramedia Pustaka Utama.
Winarno. 1997. Kimia Pangan dan Gizi. Jakarta: Gramedia Pustaka

Yetti M.A. 2009. Toksisitas Inserktisida Decis Terhadap Mortalitas dan Pengaruh Histologik Hepar Ikan Nila Merah Strain "Lokal Cangkringan". Skripsi. Yogyakarta: Jurusan Pendidikan Biologi FMIPA UNY. 